\title{
URBAN CONSUMERS' PERCEPTION ON PROCESSED FRUIT PRODUCTS: A STUDY FROM KURUNEGALA DISTRICT, SRI LANKA
}

\author{
H.M.S.M. Bandaranayake ${ }^{1 *}$, W.S.C. Perera ${ }^{1}$, R.H.M.K. Ratnayake ${ }^{1}$ and J.C. \\ Edirisinghe $^{2}$
${ }^{1}$ Department of Horticulture and Landscape Gardening, Faculty of Agriculture and Plantation Management, Wayamba University of Sri Lanka, Makandura, Gonawila (NWP) 60170, Sri Lanka
${ }^{2}$ Department of Agribusiness Management, Faculty of Agriculture and Plantation Management, Wayamba University of Sri Lanka, Makandura, Gonawila (NWP), 60170, Sri Lanka

\begin{abstract}
A significant portion of locally grown fresh fruits goes waste due to lack of processing opportunities. With a view to identify potential processed products and the consumer preferences for product types, a study was conducted with urban consumers of Kurunegala District, Sri Lanka. The availability of processed fruit products was reported using a sample of 30 supermarkets. A questionnaire based consumer survey was conducted using 200 households to assess the consumer attitudes on five major products namely, jam, cordial, juice [ready-to-serve (RTS) drink / fruit nectar], pickle and chutney. Consumers' considerations on 14 factors when purchasing those products were evaluated. Consumers' main concern was on flavour, fruit species, price and package size whereas the brand, label information and certifications gained moderate attention. While advertising was the least considered factor by consumers, their concerns on nutritional facts, additives and preservatives and the country of origin were also low. Yellow colour was most preferred for jam, cordial, juice (RTS drink/fruit nectar) and pickle while brown was most liked for chutney. Moderate sweetness and sourness were preferred over high or low levels in jam, cordial, juice and chutney while moderately sour and spicy pickle was preferred. The study further revealed that commercial exploitation of the available fruit species in Sri Lanka for processing was low. Impression on lack of safety was the major limitation which prevented consumers from purchasing processed fruit products.
\end{abstract}

Keywords: availability, consumer preference, potential, processed fruits

\section{Introduction}

The diverse agro-climate in Sri Lanka accommodates over 50 fruit species which can be grown in different areas of the island (Anon, 2015). The country produces about 1 million mt of fruits annually (Anon, 2016). Most of this production is consumed locally while only $2 \%$ is exported. The health benefits of fruits are well known as they provide essential vitamins, minerals and are an excellent source of dietary fibre. The daily requirement of fruits for a balanced diet is $112 \mathrm{~g}$ per person (Anon, 2011). However, the average daily fruit consumption of Sri Lankans is $40 \mathrm{~g}$ per person, which is one of the lowest in Asia. More than $96 \%$ of the entire fruit production in the country is available for consumption in fresh form without any value addition. However, it is estimated that $30-40 \%$ of all fruits goes waste as post-harvest losses (Esham and Usami, 2006). This is particularly evident in the peak period. On the other hand, prices of fresh fruits unreasonably rise in the off season which is one of the underlying reasons for poor fruit consumption among Sri Lankans.

Whilst most fruits are best eaten fresh, processed fruits can be acceptable alternatives (Anon, 2007). The goal of processing is to deter microbial spoilage and natural physiological deterioration of the plant cells. This process not only enhances the life of perishable products but also helps withdraw the surplus produce from the market in 
the glut period, stabilizes the prices and assists in maintaining a stock of fruits to meet the demand in offseasons.

The fruit processing industry also contributes to economic development both directly and indirectly by expanding an array of supporting businesses (Anon, 2005). A thorough understanding of the factors, which affect consumer preferences for processed fruit products is essential for the development of new products and to enhance the quality of existing products.

The objective of this study was, therefore, to find out the variety of processed fruit products in the market and assess the consumer perception towards five highly demanded product types (Ekanayake et al., 2014) in urban areas of Kurunegala District. The outcome will help identify the possibilities of introducing processed products from under-exploited species and contribute to develop products preferred by consumers.

\section{Materials and Methods}

\section{Sample and Data Collection}

The study was conducted in areas within $5 \mathrm{~km}$ radius from six towns namely, Kurunegala, Kuliyapitiya, Wariyapola, Narammala, Mallawapitiya and Polgahawela of Kurunegala District (North Western Province) from January to May 2016. The available fruit based processed products were identified in 30 randomly selected supermarkets. For the consumer survey, five highly demanded product types reported by Ekanayake et al. (2014) namely, jam, cordial, juice [ready-to-serve (RTS) drinks/fruit nectar], pickle and chutney were used. A structured, pre-tested questionnaire was used in the face-to-face interviews conducted with 200 randomly selected households.

\section{Data Analysis}

Data were analyzed descriptively using MS Excel and average values were taken for each factor. The factors were price, brand, country of origin, package size, acidity, colour, flavour, label information, nutritional facts, additives and preservatives, certification (e.g. ISO / SLS), fruit species, past purchase experience and advertising.

\section{Results and Discussion}

\section{Availability of Processed Fruit Products}

Altogether 24 fruit species have been used in processed forms (Table 1). Products from apple, date and pomegranate were imported while both imported and local products were available from strawberry. About 12 different product types were available.

The number of fruit species used in processed forms in the descending order were, fruit nectar (18), cordial (15), RTS drink/juice (13), jam (11), jelly (8), chutney (7), fruit-in-syrup (6), candy (5), pickle (3), canned fruit (2), paste (2) and dried fruit snacks (2) (Table 1). The number of processed product types from different species, in the descending order were, mango (Mangifera indica; 10), pineapple (Ananas comosus; 9), orange (Citrus sinensis; 7), lime (Citrus aurantifolia; 6), papaya (Carica papaya; 6), guava (Psidium guajava; 5), passion fruit (Passiflora edulis; 5), strawberry (Fragaria $\times$ ananassa; 5), apple (Malus domestica; 4), grapes (Vitis vinifera; 5), tamarind (Tamarindus indica; 4), wood apple (Limonia acidissima; 3), banana (Musa spp; 2), ambarella (Spondias dulcis; 2), goraka (Garcinia quaesita; 2), lemon (Citrus limon; 2), mandarin (Citrus reticulata; 2), nelli (Phyllanthus emblica; 2), and pomegranate (Punica granatum; 2). Anoda (Anonna spp.), beli (Aegle marmelos), date (Phoenix dactylifera), and melon (Citrullus lanatus) had one product each. 


\section{Potential for New Products}

Mango and pineapple have been exploited by the processing industry at a relatively higher level. However, many other species, including banana which is the most abundantly produced fruit, have limited processed forms. Moreover, some highly seasonal fruits such as rambutan (Nepheleum lappaceum), mangosteen (Garcinia mangostana), avocado (Persea americana) and durian (Durio zibethinus) have not been used for processing. Considering the availability and popularity in the international market, potential processed forms have been suggested for selected fruit species in Table 2. Ketipearachchi (2014) presented the nutritional benefits and potential processed products from a variety of under-utilized fruit species in Sri Lanka.

Table 1. Availability of processed fruit products in urban areas of Kurunegala District

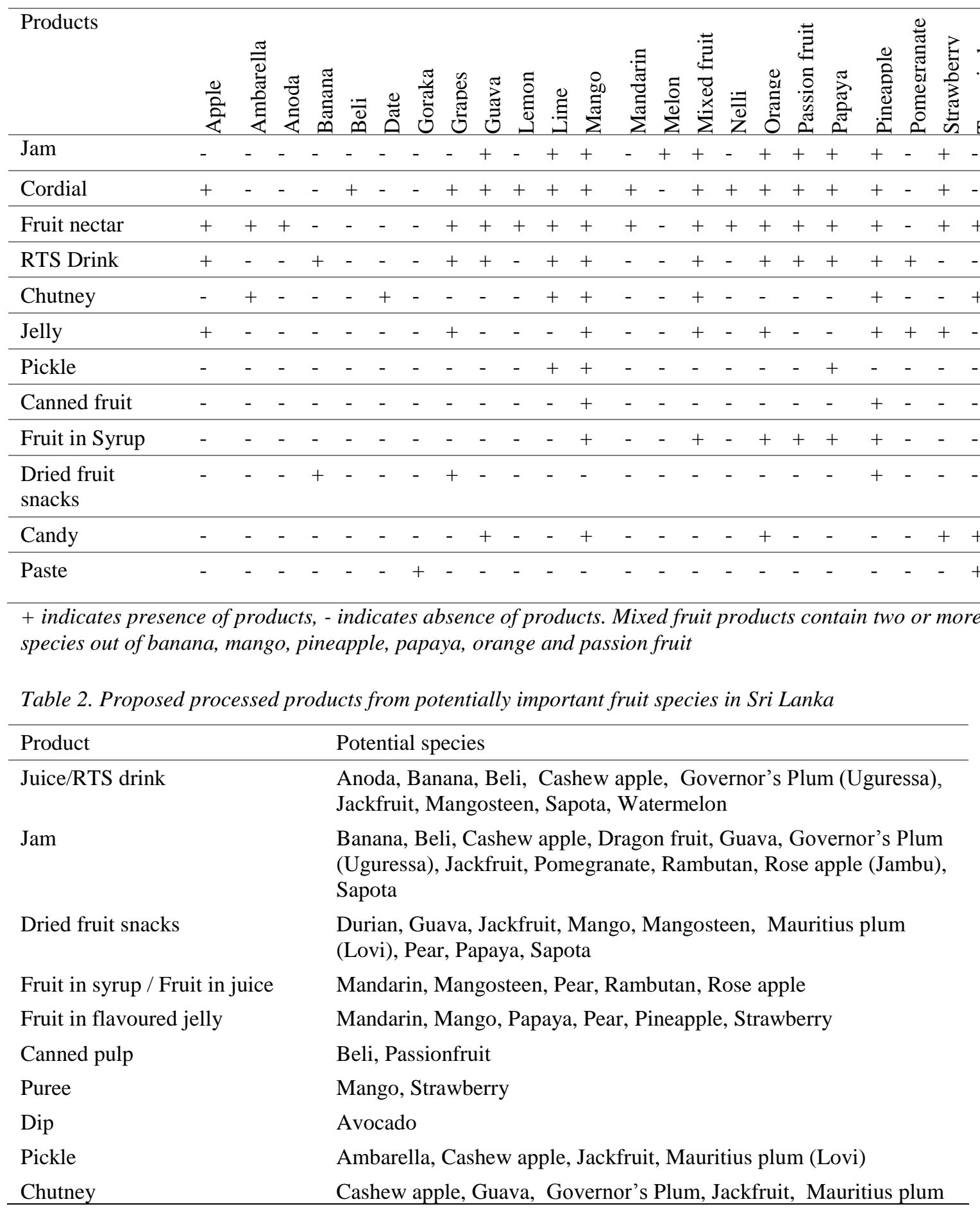




\section{Consumer Survey}

\section{Demographic Information of Consumers}

Out of the respondents participated in the consumer survey, $77 \%$ were females while $23 \%$ were males (Table 3 ).

\section{Reasons for Processed Fruit Consumption}

Out of five options, each consumer was given the freedom to select more than one option. A majority $(61.5 \%)$ of them indicated 'Convenience' as the reason for consuming processed fruits and it could be attributed to the busy life style of urban consumers. Taste was also an important reason as mentioned by $47 \%$ of respondents (Figure 1). Thus, the demand and acceptance for processed fruit products among urban consumers is likely to increase in future as the demand for convenient foods is on the rise.

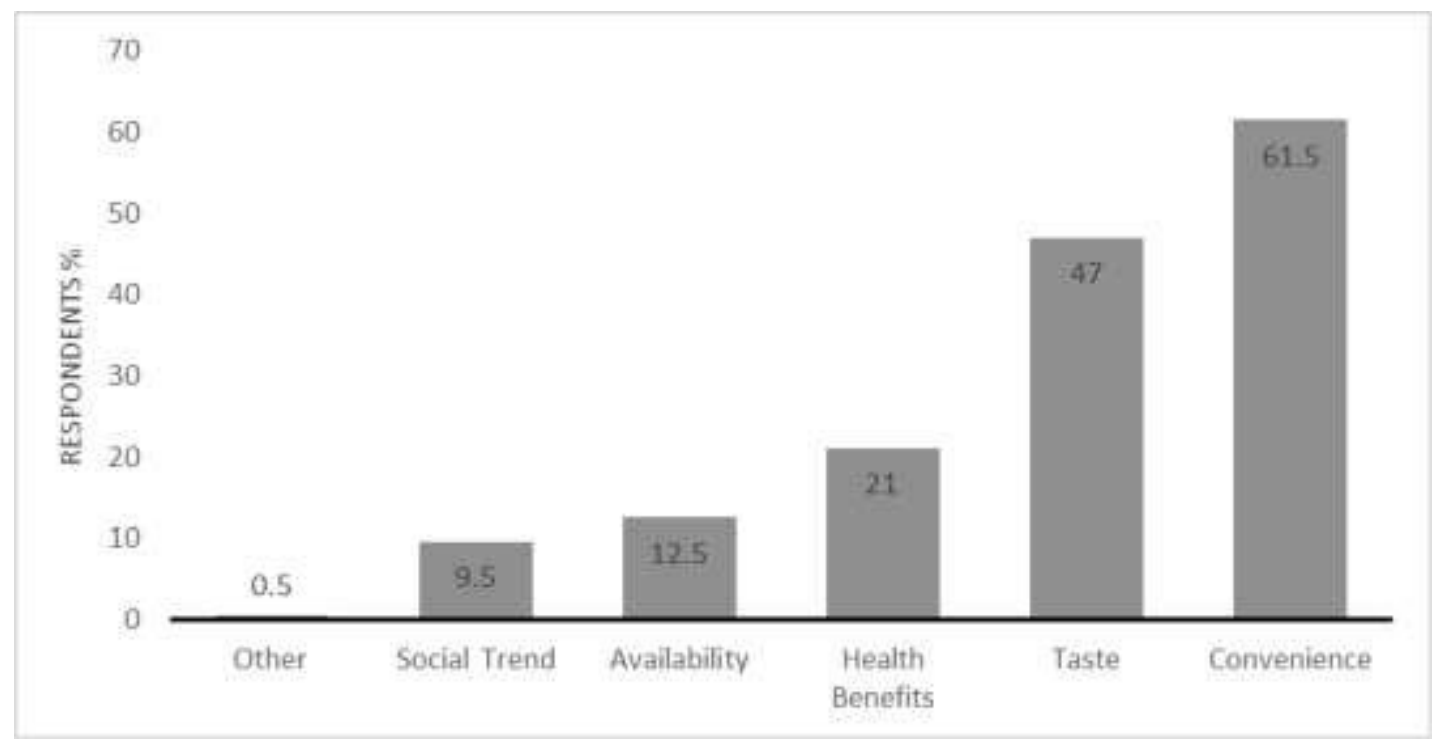

Figure 1. Reasons for consuming processed fruit products by urban consumers.

Table 3. Descriptive statistics of the sample

\begin{tabular}{ll}
\hline Attribute & Percentage of participants $(\%)$ \\
\hline Gender & 23 \\
Male & 77 \\
Female & \\
\hline Education & 4 \\
Primary & 27.5 \\
O/L & 43 \\
A/L & 10 \\
Diploma & 14 \\
Degree & 1.5 \\
Postgraduate & \\
\hline Employment & 20 \\
Government & 29 \\
Private & 16.5 \\
Own business & 34.5 \\
Not employed & \\
\hline Income Level & \\
\hline
\end{tabular}




\begin{tabular}{ll}
\hline (RS. / month) & \\
Below 25,000 & 21.5 \\
$25,000-50,000$ & 42 \\
$50,000-75,000$ & 20 \\
$75,000-100,00$ & 13.5 \\
Above 100,000 & 3 \\
\hline
\end{tabular}

\section{Consumers' Perception on Processed Fruit Products}

When purchasing the selected processed fruit products - jam, cordial, juice, pickle and chutney- consumers' main concern was on flavour, fruit species, price and package size as indicated by their higher average values (Figure 2). They had moderate consideration on brand, label information and certification details. Advertising, nutritional facts, country of origin, and the information on additives and preservatives gained least consideration. Consumers paid more attention to fruit species because flavour differs according to the species even within the same product category. Fruit juice is available either as RTS drink or fruit nectar. The juice percentage is higher in RTS drink compared to that of fruit nectar. However, nearly $18 \%$ of respondents were not aware of the difference and they considered both as the same. For those selected products, local producers (e.g. MD, KVC, CIC and Kist) have dominated the market and therefore, consumers' consideration on Country of origin was low. The product prices change based on the package size. Therefore, a high consumer attention was on the package size (Figure 2).

When purchasing jam, cordial, juice (RTS drink/fruit nectar) and pickle, yellow colour products received the highest consumer preference. However, with regard to chutney, brown colour was most preferred (Table 4). Green was the least preferred colour for these products.

Higher consumer preference was towards jam, cordial, Juice and chutney with Moderate Sweetness and Sourness levels. Further, pickle with moderate sourness and spiciness was preferred (Table 5).

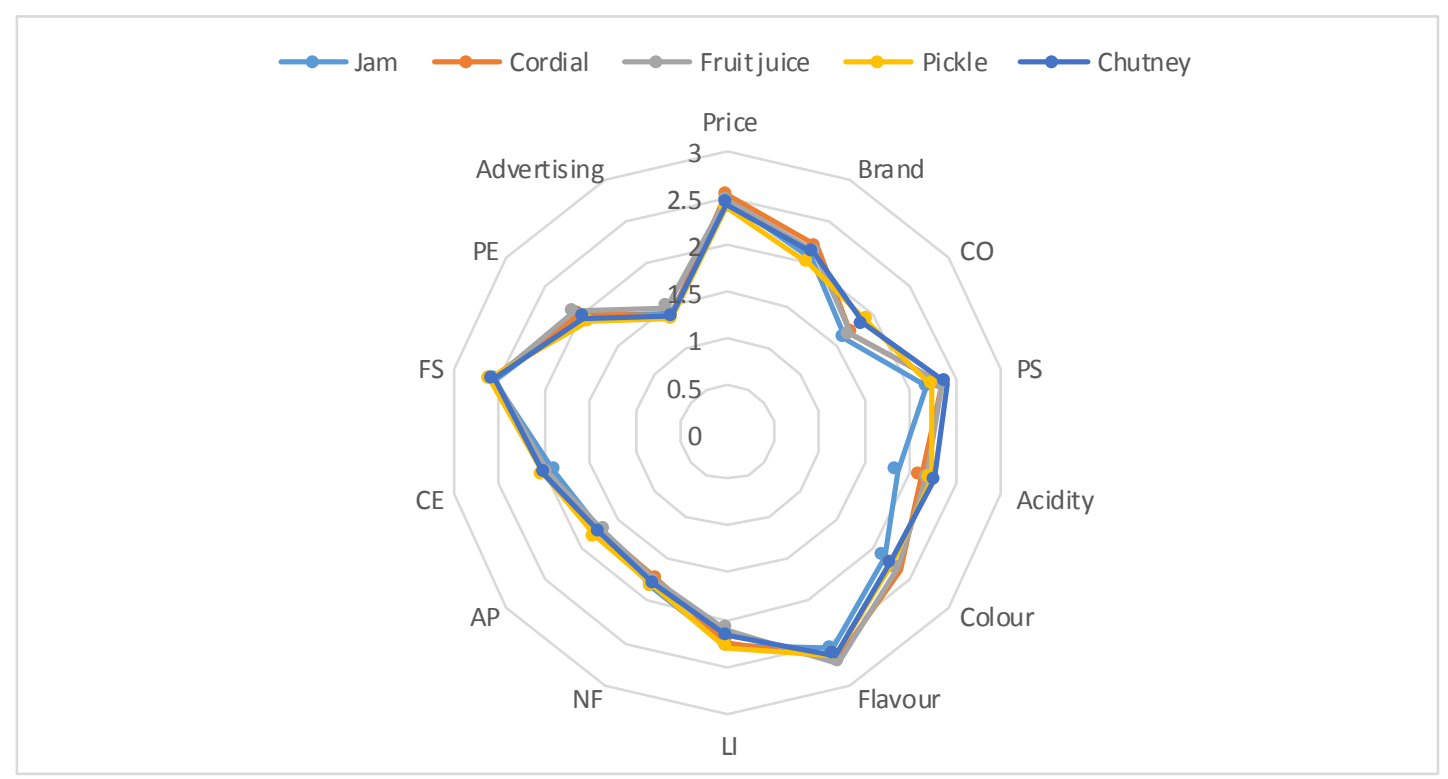

Figure 2. Consumer perception on attributes of processed fruit products. (CO-Country of origin, PS- Package size, LI-Label information, NF-Nutritional facts, AP-Additives and preservatives, CE-Certification, FS- Fruit species, PE-Past purchase experience. 
Table 4. Consumer preference for colour when purchasing jam, cordial, ready-to-serve (RTS) drink/fruit nectar, pickle and chutney

\begin{tabular}{llllll}
\hline Colour & Yellow & Orange & Red & Brown & Green \\
\hline Jam & 1.67 & - & 1.88 & 2.44 & - \\
Cordial & 1.80 & 2.35 & 3.25 & 3.74 & 3.86 \\
RTS drink/ & 1.86 & 2.45 & 3.24 & 3.35 & 4.09 \\
Fruit nectar & & & & & 3.52 \\
Pickle & 2.48 & 3.20 & 3.24 & 2.57 & 4.12 \\
Chutney & 2.67 & 2.77 & 2.92 & 2.47 & \\
\hline
\end{tabular}

For colour of Jam, maximum average value $=1$, minimum average value $=3$. For colour of Cordial, RTS drink/Fruit nectar, Pickle and Chutney, maximum average value $=1$, minimum average value $=5$

\section{Limitations for Processed Fruit Consumption}

Out of the four options viz. lack of safety, cost, low palatability and unavailability, each consumer was given the freedom to select more than one option. Among the factors that limited the consumption of processed fruit products, impression on lack of safety due to addition of preservatives, artificial colours and flavours were expressed by $58 \%$ of respondents (Figure 3 ). It was followed by the high cost $(43 \%)$. It indicates that the use of natural flavours/colours and relatively safer preservatives, and simultaneously increasing the consumer awareness on that would likely to increase popularity of processed products.

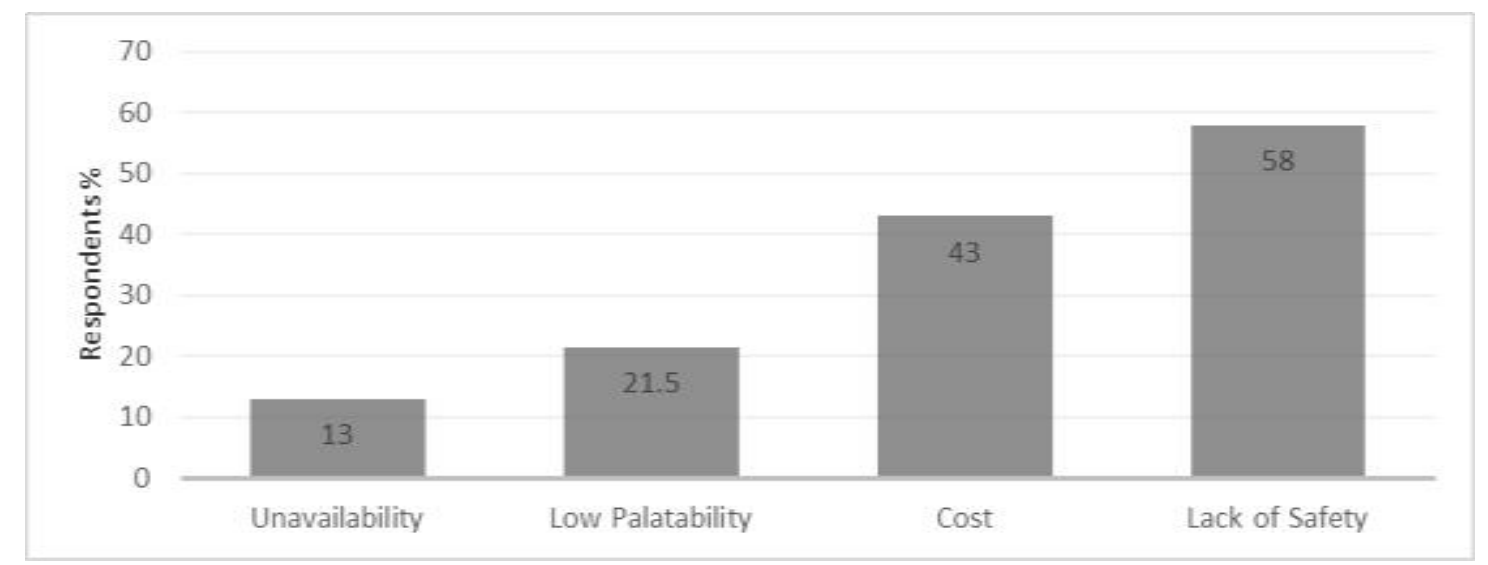

Figure 3. Limitations for the purchase of processed fruit product by consumers. 
Table 5. Consumer preference for sweetness, sourness and spiciness when purchasing jam, cordial, ready-toserve (RTS) drink/fruit nectar

$\begin{array}{ll}\text { Jam Cordial } & \text { RTS drink/ } \\ & \text { Fruit nectar }\end{array}$

\begin{tabular}{|c|c|c|c|c|c|}
\hline \multicolumn{6}{|l|}{ Sweetness } \\
\hline & 2.3 & 2.27 & 1.77 & - & 2.53 \\
\hline High & 1.4 & 1.44 & 1.68 & - & 1.36 \\
\hline Moderate & 2.3 & 2.29 & 1.95 & - & 2.11 \\
\hline \multicolumn{6}{|l|}{ Low } \\
\hline Sourness & 2.7 & 2.62 & 2.56 & 2.33 & 2.55 \\
\hline High & 1.5 & 1.43 & 1.48 & 1.41 & 1.35 \\
\hline Moderate & 1.9 & 1.99 & 2.08 & 2.26 & 2.09 \\
\hline \multicolumn{6}{|l|}{ Low } \\
\hline \multicolumn{6}{|l|}{ Spiciness } \\
\hline High & - & - & - & 2.30 & - \\
\hline Moderate & - & - & - & 1.30 & - \\
\hline Low & - & - & - & 2.39 & - \\
\hline
\end{tabular}

Maximum averages value $=1$ and minimum average value $=3$.

\section{Conclusions}

The study revealed that commercial exploitation of the available fruit species in Sri Lanka for processing is low. While entrepreneurs should be encouraged, research on new product development and investigations into their physico-chemical properties are essential. Consumers' purchasing decision is mostly based on flavour and price. However, issues in lack of safety prevented consumers from purchasing the products. Therefore, developing products with no or minimum levels of artificial compounds would promote their consumption.

\section{Acknowledgements}

The authors thank all the participants of consumer survey.

\section{References}

Anon. (2005). Asian tropical fruits deliver social and economic benefits. Available from: http://http://www.underutilized-species.org. (Accessed 03 May 2016).

Anon. (2007). Estimation of demand for processed fruit and vegetable products. Available from: www.aup.edu.pk. (Accessed 02 February 2016).

Anon. (2011). Fruit and vegetables. Sector brief. Ceylon Chamber of Commerce. Available from: http://www.regionalblog.chamber.lk/. (Accessed 02 February 2016).

Anon. (2015). Processed fruit, vegetable and juice. Available from: http://www.srilankabusiness.com. (Accessed 02 February 2016).

Anon. (2016). AgStat Volume XIII - Pocket Book of Agricultural Statistics. Socio Economic and Planning Centre, Department of Agriculture, Peradeniya, Sri Lanka.

Esham, M. and Usami, K. (2006). Procurement behaviour of fruit and vegetable industry in Sri Lanka. The Journal of Agricultural Science, 2, 36-38. 
Ekanayake, E.M.W.D., Wijesinghe, S.A.E.C. and Edirisinghe, J.C. (2014). Availability and consumer preference on processed fruit products in Kurunegala District. In Proceedings of $13^{\text {th }}$ Agricultural Research Symposium, 7-8 August, 2014. Wayamba University of Sri Lanka, Gonawila. 290-294.

Ketipearachchi, K. (2014). Under-utilized Fruits for Nutrition and Health (In Sinhala). Department of Agriculture, Sri Lanka. 